\title{
FAKTOR MACROECONOMIC DAN BANK SPESIFIC DETERMINAN DARI PROFITABILITAS BANK DI INDONESIA DENGAN PENERAPAN INTERNET BANKING
}

\author{
Ossi Ferli
}

\begin{abstract}
The purpose of this research is to use a linier regression model and analyze the effect of macroeconomic and bank spesific factors to profitability of banks in Indonesia considering the implementation of internet banking. Spesifically we analyze the performance different between banks with internet banking and non internet banking. We use data of 30 banks in Indonesia periode of 2008 until 2010.

The result shows that macroeconomic and some of bank spesific factors also internet banking has a significant influence to banks profitability. The research also showed bank with internet banking has a better performance than non internet banking, mostly because the overall condition of the banks and that internet banking has been a complementary factor in bank service to their customer.
\end{abstract}

Keywords: Internet banking, data panel, bank spesific, macroeconomic

\section{PENDAHULUAN}

Internet telah berubah menjadi salah satu dari saluran distribusi yang dipergunakan untuk kepentingan konsumen, tepat di garda depan dari evolusi ini adalah produk dan jasa elektronik keuangan. Perubahan yang sangat cepat dari internet menyebabkan perbankan di dunia maya semakin menjadi saluran alternatif dalam menyediakan produk dan jasa bank. Menurut DeYoung, Lang, dan Nolle (2006) kemunculan internet banking jelas memiliki implikasi potensial pada jenis usaha bank, sumber dana, tenaga kerja, pertumbuhan, dan profil return dan risiko.

Menurut laporan comscore (www.w3indo.com), pengunjung online banking mengalami peningkatan yang cukup pesat di beberapa negara di Asia, Indonesia menduduki posisi teratas pada tahun 2011. Online banking di Indonesia mengalami peningkatan pengunjung hingga $72 \%$, sedangkan pasar untuk online banking di Indonesia masih terbuka lebar, dimana pengguna jasa online banking baru sekitar $1.5 \%$ dari seluruh pengguna internet di Indonesia.

Peningkatan pengguna online banking dan pasar pengguna jasa online banking di Indonesia yang cukup besar tentu merupakan hal yang menarik untuk diteliti. Beberapa bank mungkin merasa penerapan internet banking hanya merupakan penambahan dari segi biaya sehingga akan mengurangi profit, sedangkan beberapa bank lain merasa penerapan internet banking akan menarik lebih banyak konsumen potensial mereka.

Internet banking di Indonesia baru dimulai sejak tahun 2004. Mempelajari periode waktu awal munculnya internet banking di Indonesia dapat membantu dalam membedakan secara jelas antara bank internet banking dan bank non internet banking. Berdasarkan jurnal penelitian sebelumnya yaitu Athanasoglou, Brissimis, dan Delis (2005) yang menggunakan 
data panel bank di Yunani pada periode 1985-2001 menunjukkan bahwa profitabilitas (ROA \& ROE) dipengaruhi oleh bank spesific factors dan variabel kontrol macroeconomic factors, sedangkan industry specific tidak berpengaruh signifikan. Malhotra dan Singh (2009) melakukan penelitian pada 88 bank di India menunjukkan internet banking tidak memberikan dampak yang signifikan terhadap kinerja keuangan di India, penelitian ini juga menunjukkan penyedia jasa internet banking merupakan bank yang lebih besar. Penelitian yang dilakukan oleh DeYoung et al. (2006) mengenai pengaruh internet pada output dan kinerja community banks pada tahun 1999-2001 menyimpulkan bahwa internet banking dapat meningkatkan profitabilitas bank di Amerika. Sehingga menarik untuk melakukan penelitian mengenai "Faktor Macroeconomic dan Bank Specific Determinan dari Profitabilitas Bank di Indonesian dengan Penerapan Internet Banking."

\section{KAJIAN TEORITIS}

\subsection{Dasar Teori}

Pengertian bank menurut UU No. 7 tahun 1992 tentang Perbankan sebagaimana telah diubah dengan UU No. 10 tahun 1998 adalah sebagai berikut:

1) Perbankan adalah segala sesuatu yang menyangkut tentang bank, mencakup kelembagaan, kegiatan usaha serta cara dan proses dalam melaksanakan kegiatan usahanya.

2) Bank adalah badan usaha yang menghimpun dana dari masyarakat dalam bentuk simpanan, dan menyalurkannya kepada masyarakat dalam bentuk kredit dan atau bentuk-bentuk lainnya dalam rangka meningkatkan taraf hidup masyarakat banyak.

3) Bank umum adalah bank yang melaksanakan kegiatan usaha secara konvensional dan atau berdasarkan prinsip yang dalam kegiatannya memberikan jasa dalam lalu lintas pembayaran.

4) Bank perkreditan rakyat adalah bank yang melaksanakan kegiatan usaha secara konvensional atau berdasarkan prinsip syariah yang dalam kegiatannya tidak memberikan jasa dalam lalu lintas pembayaran.

Bank pemerintah dan swasta nasional yang terdaftar sebagai emiten di Bursa Efek Indonesia pada periode penelitian akan menjadi objek penelitian.

Secara umum, tipe jasa yang ditawarkan bank melalui internet (Keown, 2004):

a. Basic level, dimana website bank hanya memberikan informasi seputar bank serta produk dan jasa yang ditawarkan.

b. Simple transactional, website dapat dimanfaatkan untuk interaksi konsumen seperti pengisian aplikasi untuk jasa lain, informasi saldo, nilai tukar mata uang, dan lainnya namun tidak menyediakan sarana untuk melakukan transaksi.

c. Fully transactional, website dapat melakukan transaksi yang melibatkan arus dana seperti transfer, pembayaran tagihan, transaksi pembelian sekuritas, dan sebagainya.

Penelitian ini akan menganalisis bank dengan jasa pelayanan internet tipe simple transactional dan fully transactional.

Menurut Ikatan Akuntansi Indonesia (IAI, 2007) kinerja perusahaan dapat diukur dengan menganalisis dan mengevaluasi laporan keuangan. Informasi posisi keuangan dan 
kinerja keuangan di masa lalu seringkali digunakan sebagai dasar untuk memprediksi posisi keuangan dan kinerja di masa depan.

Rasio profitabilitas yang digunakan dalam penelitian adalah ROA karena merefleksikan kemampuan bank dalam memanfaatkan investasi dalam bentuk aset untuk menghasilkan laba. Rasio ini merupakan salah satu unsur yang umum digunakan dalam mengukur tingkat kesehatan bank.

$$
\mathrm{ROA}=\frac{\text { Net Profit Before Tax }}{\text { Total Assets }}
$$

Macroeconomic factor yang digunakan adalah tingkat suku bunga bank Indonesia (BI Rate), karena dianggap memiliki pengaruh langsung yang kuat pada bank di Indonesia. Bi Rate dipilih karena merupakan alat kebijakan moneter yang digunakanoleh Bank Indonesia. Bank spesific factors yang digunakan pada penelitian ini sesuai dengan Athanasoglou et al. (2005) yaitu:

1. Equity to asset (EA) menjadi proksi variabel capital. Equity yang tinggi mencerminkan modal bank yang tinggi, sehingga expected earning-nya lebih besar dibandingkan dengan bank yang membutuhkan pembiayaan eksternal yang tinggi, maka variabel ini juga diekspektasikan bertanda positif pada profitabilitas.

2. Loans to asset (LA) menjadi proksi variabel credit risk. Loans semakin tinggi menghasilkan pendapatan dari bunga kredit semakin tinggi, dengan asumsi kolektibilitas dari bunga dan modal yang dipinjamkan lancar atau tidak bermasalah, maka akan berpengaruh positif pada profitabilitas.

3. Operational Cost (OC) menjadi proksi variabel expenses management. Operational Cost yang tinggi menunjukkan bahwa manajemen tersebut tidak efektif dalam hal efisiensi beban biaya non-tradisional maka akan berpengaruh negatif pada profitabilitas.

$$
\text { OPCOST }=\frac{\begin{array}{l}
\text { Non Interest } \\
\text { Exspenses }
\end{array}}{\begin{array}{l}
\text { Net Operating } \\
\text { Revenue }
\end{array}}
$$

4. Log asset ( $\log A)$ menjadi proksi variabel size. Semakin besar ukuran bank, semakin besar kesempatan dan kemampuan bank tersebut untuk meningkatkan laba.

\subsection{Gap Penelitian}

Penelitian mengenai pengaruh faktor makroekonomi dan spesifik bank terhadap profitabilitas bank di Indonesia dengan memperhitungkan penerapan internet banking belum banyak dilakukan. Penelitian mengenai profitabilitas bank yang dilakukan oleh Athanasoglou et al. (2005), DeYoung et al. (2006), dan Maholtra \& Singh (2009) menjadi acuan dalam membuat model penelitian. Namun penelitian ini menggunakan metodologi yang berbeda, serta menganalisis apakah ada perbedaan pada bank yang menerapkan internet banking dan yang tidak menerapkan internet banking. 
Faktor Macroeconomic...

\section{DATA DAN METODOLOGI}

\subsection{Data}

Data yang digunakan dalam penelitian ini menggunakan data panel (balanced). Data panel (balanced) adalah jenis data yang merupakan gabungan antara data runtut waktu (time series) dengan data seksi silang (cross section). Data keuangan diperoleh dari data stream Reuters merupakan data sekunder laporan keuangan, khususnya laporan laba/rugi dan neraca bank. Sedangka data inflasi diperoleh dari www.bi.go.id.

Objek penelitian terdiri dari bank pemerintah dan swasta nasional yang terdaftar sebagai emiten di Bursa Efek Indonesia, bank dengan jasa pelayanan internet tipe simple transactional dan fully transactional. Terdapat 30 bank yang akan menjadi objek penelitian, dapat dilihat di Lampiran. Bank yang menerapkan internet banking selama $\geq 2$ tahun baru dianggap sebagai kelompok bank yang menerapkan internet banking.

Ruang lingkup penelitian dibatasi pada periode 2008 hingga 2010, sehingga jumlah periode pengamatannya adalah 3 tahun. Pemilihan batas periode ini dikarenakan menurut survey yang telah dilakukan, bank penyedia jasa internet banking di Indonesia baru bermunculan pada tahun 2004 dan setelah ditambah 2 tahun pengembangan yang dilakukan oleh bank, maka peneliti menganggap bahawa pada periode tersebut, setiap bank telah merasakan dampak yang cukup signifikan.

Variabel dependen profitabilitas yang digunakan adalah ROA yang sering menjadi acuan sebagai bank's equity multiplier. Penelitian ini memasukkan faktor potensial lain sebagai variabel penjelas yang berhubungan dengan profitabilitas bank. Karakteristik yang dipilih termasuk pada macroeconomic (BIRate) dan bank specific profitability determinants (EA, LA, OC, dan LogA). Dummy variabel yang digunakan adalah Internet (NET) dengan nilai 1 jika bank dengan internet banking, dan 0 jika tidak internet banking. Bank yang mengimplementasikan internet banking akan meningkatkan profitabilitas. Berikut kerangka pemikiran penelitian:

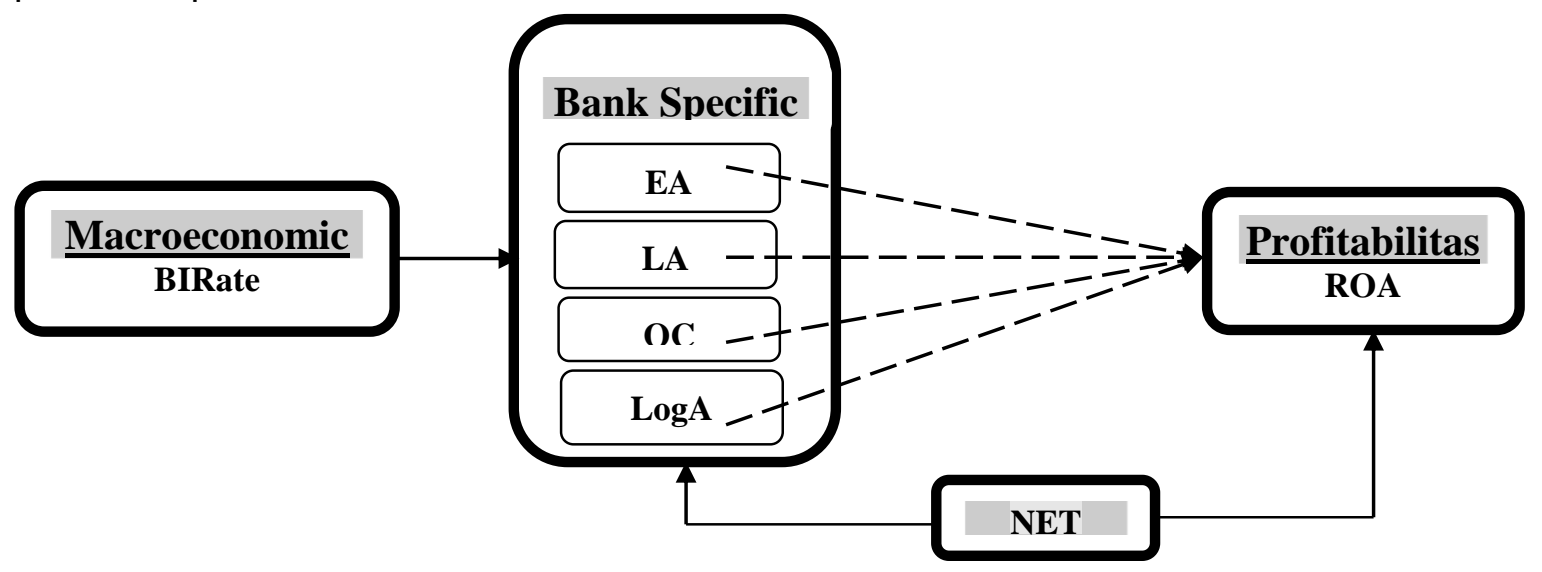

\subsection{Model Penelitian}

Penelitian mengenai profitabilitas bank yang dilakukan oleh Athanasoglou et al. (2005), DeYoung et al. (2006), dan Maholtra \& Singh (2009) menjadi acuan dalam membuat model penelitian berikut: 


\section{$\mathrm{ROA}_{\mathrm{i}, \mathrm{t}}=\alpha_{0}+\alpha_{1}$ BiRate $_{\mathrm{i}, \mathrm{t}}+\alpha_{2} \mathrm{NET}_{\mathrm{i}, \mathrm{t}}+\sum \mathbf{B}_{\mathrm{i}} \mathrm{X}_{\mathrm{i}, \mathrm{t}}+\varepsilon_{\mathrm{i}, \mathrm{t}}$ \\ ROA $_{i, t}=\alpha_{0}+\alpha_{1} B_{\text {IRate }}, t+\alpha_{2} N_{E T} T_{i, t}+\beta_{1} E_{i, t}+\beta_{2} L_{A} A_{i, t}+\beta_{3} O_{i, t}+\beta_{4} \log _{i, t}+\varepsilon_{i, t}$}

Berdasarkan model penelitian diatas, hipotesis yang akan diuji adalah

$\mathrm{H}_{1}$ : Faktor makroekonomik dan spesifik bank berpengaruh secara individu terhadap profitabilitas bank

$\mathrm{H}_{2}$ : Faktor makroekonomik dan spesifik bank berpengaruh secara bersama terhadap profitabilitas bank

$\mathrm{H}_{3}$ : Kinerja keuangan bank yang menerapkan internet banking berbeda dengan bank yang tidak menerapkan internet banking, dalam hal profitabilitas, capital, credit risk, expense management, dan size.

Berdasarkan hipotesis diatas, dilakukan analisa data.

\subsection{Analisa Data Panel}

Data yang digunakan adalah balanced panel karena setiap unit cross sectional memiliki jumlah observasi time series yang sama. Periode time series data yang digunakan kecil sehingga tidak perlu dilakukan uji stationer. Pengujian statistik yang akan dilakukan untuk menentukan model efek individu yang sesuai adalah:

a. Chow test, pengujian untuk memilih apakah model yang digunakan Pooled Least Square atau Fixed Effect. Jika nilai Prob. $<\infty$, maka hipotesa null ditolak sehingga model yang digunakan adalah Fixed Effect, begitu pula sebaliknya.

b. Hausman test, pengujian untuk memilih apakah model Fixed Effect atau Random Effect. Jika nilai Prob. $<\infty$, maka hipotesa null ditolak sehingga model yang digunakan adalah Fixed Effect, begitu pula sebaliknya.

\subsection{Uji Asumsi Klasik}

Model akan memenuhi asumsi best linier unbiased estimator (BLUE) dengan

a. Multicollineariality test, pengujian korelasi antara independent variabel. Jika korelasi antar independent variabel > 0.80 maka terdapat masalah multicollineariality yang membahayakan model.

b. Heterocedasticity test, pengujian hubungan residual model dengan salah satu independen variabel. Menggunakan White test, jika $\chi^{2}$ dof $=1<\alpha$ maka hipotesis null ditolak sehingga terdapat masalah Heterocedasticity.

c. Autocorrelation test, pengujian korelasi antara anggota serangkaian observasi yang diurutkan menurut waktu atau ruang. Menggunakan Durbin-Watson test, jika $0<\mathrm{d}<\mathrm{d}_{\mathrm{L}}$ atau $4-\mathrm{d}_{\mathrm{L}}<\mathrm{d}<4$ maka hipotesis null ditolak sehingga terdapat masalah Autocorrelation. 
Faktor Macroeconomic...

\subsection{Uji Hipotesis}

Uji hipotesis yang akan dilakukan berdasarkan hipotesis yang ada adalah

a. Uji t untuk mengetahui apakah ada pengaruh variabel independen secara individu, jika Probabilita $t<\alpha$ maka hipotesis null ditolak sehingga variabel independen secara individu memiliki pengaruh yang signifikan terhadap variabel dependen.

b. Uji F untuk mengetahui apakah ada pengaruh variabel independen secara bersama, jika Probabilita $F<\alpha$ maka hipotesis null ditolak sehingga variabel independen secara bersama memiliki pengaruh yang signifikan terhadap variabel dependen.

c. Uji beda rata-rata digunakan untuk mengetahui apakah ada perbedaan antara yang menerapkan dan tidak menerapkan internet banking.

\section{HASIL DAN DISKUSI}

\subsection{Analisa Data Panel}

Hasil uji Chow dan uji Hausman dapat dilihat pada tabel berikut:

Redundant Fixed Effects Tests
Pool: REGFIXED
Test cross-section fixed effects
\begin{tabular}{llll} 
& & & \\
\hline \hline Effects Test & Statistic & d.f. & Prob. \\
\hline \hline Cross-section F & 4.217296 & $(29,54)$ & 0.0000 \\
Cross-section Chi-square & 106.48907629 & 0.0000 \\
\hline \hline
\end{tabular}

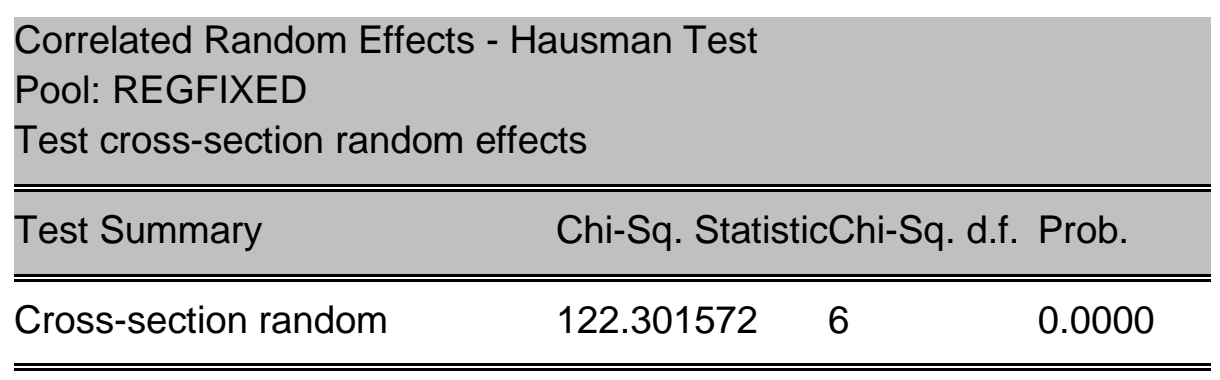

Chow test dan Hausmann test menghasilkan nilai Probabilita $0.0000<\alpha=5 \%$, maka model Fixed Effect lebih sesuai digunakan pada penelitian ini. Model ini dapat menunjukkan perbedaan konstan antar objek, meskipun dengan koefisien regresor yang sama. Hal ini dapat diterima karena objek yang digunakan dalam penelitian ini merupakan kelompok objek yang berada pada satu industri yang sama yaitu perbankan.

\subsection{Analisa Uji Asumsi Klasik}

Penelitian ini menggunakan model regresi linier berganda. Permasalahan yang mungkin terjadi adalah multikolinearitas, heterokedastis, dan autokorelasi.

a. Uji multikolinearitas melihat correlation matrix dimana jika angka melebihi 0.80 dianggap terdapat multikolinearitas. Model tidak ada masalah multikolinearitas. 


\begin{tabular}{|c|c|c|c|c|c|c|c|}
\hline & C & EA? & LA? & OC? & LOGA? & NET? & $\begin{array}{l}\text { BIRATE } \\
?\end{array}$ \\
\hline & 44.970 & 0.4887 & $\begin{array}{l} \\
7.62189\end{array}$ & 3.30619 & 0.0028 & $\begin{array}{l} \\
5.77379\end{array}$ & 0.4102 \\
\hline C & 82 & 22 & 7 & $\begin{array}{l}6 \\
-\end{array}$ & 77 & $\begin{array}{l}8 \\
-\end{array}$ & $\begin{array}{l}00 \\
-\end{array}$ \\
\hline & & 0.5220 & 0.0074 & 0.03973 & 5.64E- & 0.06383 & 0.00210 \\
\hline EA? & & 72 & 32 & $\begin{array}{l}5 \\
-\end{array}$ & $\begin{array}{l}05 \\
-\end{array}$ & 1 & $\begin{array}{l}4 \\
-\end{array}$ \\
\hline LA? & & & $\begin{array}{l}40.342 \\
27\end{array}$ & $\begin{array}{l}0.44301 \\
3\end{array}$ & $\begin{array}{l}0.00169 \\
2\end{array}$ & $\begin{array}{l}0.5357 \\
02\end{array}$ & $\begin{array}{l}1.04079 \\
9 \\
-\end{array}$ \\
\hline OC? & & & & $\begin{array}{l}3.5778 \\
19\end{array}$ & $\begin{array}{l}0.0004 \\
50\end{array}$ & $\begin{array}{l}0.1734 \\
75 \\
-\end{array}$ & $\begin{array}{l}0.06457 \\
6\end{array}$ \\
\hline LOGA? & & & & & $\begin{array}{l}1.78 E- \\
05\end{array}$ & $\begin{array}{l}0.00038 \\
8 \\
0.7675\end{array}$ & $\begin{array}{l}6.00 \mathrm{E}- \\
06 \\
- \\
0.04604\end{array}$ \\
\hline $\begin{array}{l}\text { NET? } \\
\text { BIRATE? }\end{array}$ & & & & & & 43 & $\begin{array}{l}0 \\
0.2780 \\
32\end{array}$ \\
\hline
\end{tabular}

b. Uji heterokedastis dapat diatasi dengan Generalized Least Square, hasil yang ditampilkan oleh Eviews sudah bersifat homoskedastis sehingga tidak perlu pengujian lebih lanjut.

c. Uji autokorelasi berdasarkan nilai statistik Durbin Watson yaitu 2.25 berada pada daerah tengah dan menunjukkan tidak ada masalah autokorelasi.

Maka model regresi linier pada penelitian ini sudah memenuhi asumsi BLUE.

\subsection{Analisa Uji Hipotesis}

Hasil uji t dan uji F model yang sesuai dapat dilihat pada tabel berikut:

\begin{tabular}{lllll}
\hline Variable & Coefficient & Std. Error & t-Statistic & Prob. \\
\hline \hline C & 1941.147 & 4.462860 & 434.9558 & 0.0000 \\
EA? & 0.840801 & 0.264383 & 3.180240 & $0.0024^{*}$ \\
LA? & 9.351303 & 2.906383 & 3.217506 & $0.0022^{*}$ \\
OC? & 1.536069 & 1.381295 & 1.112050 & 0.2710 \\
LOGA? & 0.003104 & 0.003524 & 0.880781 & 0.3823 \\
NET? & 8.966526 & 0.530161 & 16.91285 & $0.0000^{*}$ \\
BIRATE? & 1.013585 & 0.198626 & 5.102974 & $0.0000^{*}$ \\
\hline R-squared & 0.912266 & & & \\
F-statistic & 16.04286 & Durbin-Watson stat & 2.248494 \\
Prob(F-statistic) & 0.000000 & & & \\
* signifikan pada alpha 5\%
\end{tabular}


Faktor Macroeconomic...

a) Hasil uji t menunjukkan pengaruh variabel independen secara individu pada variabel dependen.

- Faktor capital (EA) positif dan signifikan secara statistik berpengaruh pada ROA, hal ini menunjukkan kemampuan bank dalam mengejar kesempatan investasi secara efektif.

- Faktor credit (LA) positif dan signifikan secara statistik berpengaruh pada ROA, hal ini menunjukkan bank melakukan strategi risk averse dalam berinvestasi, dengan meningkatkan pengawasan risiko kredit.

- Faktor expense management (OC) positif dan tidak signifikan secara statistik, hal ini menunjukkan biaya operasional bank sudah efisien sehingga tidak berpengaruh lagi pada profitabilitas bank.

- Faktor size (LOGA)positif dan tidak signifikan secara statistik, hal ini menunjukkan ukuran bank tidak penting dalam profitabilitas, mungkin karena bank berusaha untuk tumbuh cepat dengan menggunakan profitabilitasnya.

- Faktor internet banking (NET) positif dan signifikan secara statistik, hal ini menunjukkan internet banking merupakan faktor komplementer dalam penawaran jasa bank bagi konsumen sehingga meningkatkan profitabilitas.

- Faktor makroekonomi (BIRATE) positif dan signifikan secara statistik, hal ini menunjukkan penetapan tingkat suku bunga oleh bank sentral menjadi pedoman bagi bank-bank di Indonesia sehingga sangat berpengaruh.

b) Berdasarkan hasil uji $\mathrm{F}$ maka variabel-variabel independen pada model secara bersama memiliki pengaruh yang signifikan secara statistik. Variabel-variabel yang ada dalam model berhasil menjelaskan profitabilitas (ROA) sebesar $91.23 \%$. Hal ini menunjukkan bahwa faktor makroekonomi, bank spesifik, dan internet banking yang dipilih dalam model mempengaruhi profitabilitas bank-bank di Indonesia.

c) Berdasarkan hasil uji beda rata-rata kelompok bank yang menerapkan internet banking dan tidak menerapkan internet banking pada masing-masing variabel profitabilitas dan faktor spesifik bank diperoleh hasil sebagai berikut:

\begin{tabular}{|c|c|c|c|}
\hline & $\begin{array}{l}\text { Internet Banks } \\
\left(\mathrm{N}_{1}=24\right) \\
\text { Mean }\end{array}$ & $\begin{array}{l}\text { Non Internet Banks } \\
\left(\mathrm{N}_{2}=66\right) \\
\text { Mean }\end{array}$ & $\begin{array}{l}\text { Signifikansi Statistik dari } \\
\text { Uji Beda Rata-rata } \\
\text { F-statistik }\end{array}$ \\
\hline ROA & 0.01889 & 0.00006 & $\begin{array}{l}3286.785 \\
(0.0000)\end{array}$ \\
\hline EA & 0.09793 & 0.10708 & $\begin{array}{l}107.4472 \\
(0.0000)\end{array}$ \\
\hline LA & 0.59409 & 0.58499 & $\begin{array}{l}153.9296 \\
(0.0000)\end{array}$ \\
\hline OC & -0.01369 & -9.65177 & $\begin{array}{l}204.3237 \\
(0.0000)\end{array}$ \\
\hline $\log A$ & 8.02828 & 7.07538 & $\begin{array}{l}287.5883 \\
(0.0000)\end{array}$ \\
\hline
\end{tabular}


Berdasarkan hasil tersebut maka kinerja bank yang menerapkan internet banking memang berbeda signifikan secara statistik dengan bank yang tidak menerapkan internet banking dalam hal profitabilitas dan faktor spesifik bank.

- Perbandingan rata-rata profitabilitas (ROA), bank yang menerapkan internet banking memiliki rata-rata profit yang lebih besar daripada bank yang tidak menerapkan internet banking.

- Perbandingan rata-rata capital (EA), bank yang menerapkan internet banking sedikit lebih kecil daripada yang tidak menerapkan. Namun jumlah bank yang menerapkan memang lebih kecil daripada yang tidak diimbangi oleh kenyataan bahwa bank-bank dengan modal besar yang menerapkan internet banking.

- Perbandingan rata-rata credit (LA), bank yang menerapkan internet banking lebih besar daripada yang tidak menerapkan. Menunjukkan bank yang menerapkan memang sudah lebih banyak berinvestasi pada kredit dan memang berhasil mendapatkan konsumen potensial nya.

- Perbandingan rata-rata expense management (OC), bank yang menerapkan internet banking lebih kecil daripada yang tidak menerapkan. Menunjukkan bank yang menerapkan internet banking adalah bank yang sudah efisien dalam operasional.

- Perbandingan rata-rata size $(\log A)$, bank yang menerapkan internet banking lebih besar daripada yang tidak menerapkan. Menunjukkan bank yang menerapkan memang lebih besar ukurannya perusahaannya.

\section{KESIMPULAN DAN SARAN}

Kesimpulan yang dapat diambil berdasarkan analisa faktor makroekonomi dan spesifik bank di Indonesia dengan penerapan internet banking:

1. Pengaruh faktor makroekonomi dan spesifik bank memang memiliki pengaruh yang cukup kuat pada profitabilitas bank di Indonesia baik secara individu. Hal ini sesuai dengan hasil penelitian sebelumnya yang dilakukan oleh Athanasoglou (2006) yang meneliti bank di Amerika. Namun tidak semua faktor bank spesifik yang berpengaruh secara signifikan pada profitabilitas, yang berpengaruh signifikan adalah faktor yang berhubungan dengan strategi investasi dan pengelolaan risiko bank. Faktor spesifik bank seperti expense management dan size tidak memiliki pengaruh yang signifikan, hal ini menunjukkan sebagian besar bank di Indonesia sudah efisien dalam operasionalnya dan ukuran bank tidak mempengaruhi profitabilitas bank tersebut.

2. Pengaruh faktor makroekonomi dan spesifik bank memang memiliki pengaruh yang cukup kuat pada profitabilitas bank di Indonesia baik secara bersama. Hal ini ditunjukkan dengan koefisien determinasi yang cukup tinggi sebesar $91.23 \%$, sehingga $8.77 \%$ dapat dijelaskan oleh variabel lain diluar penelitian ini.

3. Hasil penelitian menunjukkan adanya perbedaan antara bank yang menerapkan internet banking dan yang tidak menerapkan internet banking dalam hal profitabilitas, capital, credit risk, expense management, dan size. Terlihat bank-bank yang menerapkan internet banking di Indonesia memang merupakan bank-bank yang sudah mapan dan efisien dalam menjalankan usahanya yang merupakan 
Faktor Macroeconomic...

sepertiga dari total bank yang terdaftar di Bursa Efek Indonesia. Hal ini sesuai dengan hasil penelitian yang dilakukan oleh Malhotra dan Singh (2009).

Saran berdasarkan hasil penelitian ini adalah:

1. Untuk penelitian selanjutnya bisa memperhitungkan adanya pengaruh profitabilitas lag sebelumnya pada model analisa, mengingat profitabilitas biasanya menunjukkan perubahan yang tidak terlalu besar, merefleksikan kurang kuatnya kompetisi dalam pasar, sehingga ada kemungkinan adanya spesifikasi dinamis dari model terutama jika periode penelitian lebih panjang.

2. Penelitian selanjutnya juga dapat memasukkan variabel lain dari faktor makroekonomi yang ada seperti inflasi, GDP, jumlah uang beredar, dan kurs mata uang. Sebagai tambahan juga dapat memasukkan variabel dari faktor industry specific seperti jenis kepemilikan bank.

\section{DAFTAR PUSTAKA}

Athanasoglou, P.P., Brissimis, S. N. and Delis, M.D. (2005). "Bank-Specific, IndustrySpecific and Macroeconomic Determinants of Bank Profitability", Working Paper No. 23, Bank of Greece, June.

DeYoung, Robert, William W. Lang, dan Daniel L. Nolle. (2006). "How the Internet Affects Output and Performance at Community Banks". Journal of banking and finance.

Gujarati, Damodar N. (2003). "Basic Econometrics". 4th Edition. McGraw-Hill.

Ikatan Akuntansi Indonesia, (2007). "Standar Akuntansi Keuangan". Jakarta : Penerbit Salemba Empat

Keown, Arthur. (2004). Financial Management: Principles and Analysis“. 9th Edition. Boston: Prentice Hall. .

Malhotra, Pooja dan Balwinder Singh. (2009). "The Impact of Internet Banking on Bank's

Performance: The Indian Experience". Eurasian Journal of Business and Economics, 43-62. Reuters Data Stream

Winarno, W.W. (2009). "Analisis Ekonometrika dan Statistika dengan EViews". Edisi kedua, Unit penerbit dan percetakan STIM YKPN.

www.bi.go.id

www.w3indo.com

\section{LAMPIRAN}

Seluruh objek penelitian bank yang terdaftar sebagai emiten di Bursa Efek Indonesia pada periode penelitian

\begin{tabular}{|l|l|l|l|l|l|}
\hline NO & KODE & BANK & NO & KODE & BANK \\
\hline 1 & AGRO & Bank Agro Niaga Tbk & 16 & BNBA & Bank Bumi Arta Tbk \\
\hline 2 & BABP & Bank ICB Bumiputera Tbk & 17 & BNGA & Bank CIMB Niaga Tbk \\
\hline 3 & BACA & Bank Capital Indonesia Tbk & 18 & BNII & $\begin{array}{l}\text { Bank Internasional Indonesia } \\
\text { Tbk }\end{array}$ \\
\hline 4 & BAEK & Bank Ekonomi Raharja Tbk & 19 & BNLI & Bank Permata Tbk \\
\hline
\end{tabular}


Faktor Macroeconomic ...

\begin{tabular}{|c|c|c|c|c|c|}
\hline 5 & BBCA & Bank Central Asia Tbk & 20 & BSIM & Bank Sinar Mas Tbk \\
\hline 6 & BBKP & Bank Bukopin Tbk & 21 & BSWD & Bank Swadesi Tbk \\
\hline 7 & BBNI & $\begin{array}{l}\text { Bank Negara Indonesia } \\
\text { (Persero) Tbk }\end{array}$ & 22 & BTPN & $\begin{array}{l}\text { Bank Tabungan Pensiun } \\
\text { Nasional Tbk }\end{array}$ \\
\hline 8 & BBNP & $\begin{array}{l}\text { Bank Nusantara } \\
\text { Parahyangan Tbk }\end{array}$ & 23 & BVIC & Bank Victoria International Tbk \\
\hline 9 & BBRI & $\begin{array}{l}\text { Bank Rakyat Indonesia } \\
\text { (Persero) Tbk }\end{array}$ & 24 & INPC & $\begin{array}{l}\text { Bank Artha Graha International } \\
\text { Tbk }\end{array}$ \\
\hline 10 & BBTN & $\begin{array}{l}\text { Bank Tabungan Negara } \\
\text { (Persero) Tbk }\end{array}$ & 25 & MAYA & $\begin{array}{l}\text { Bank Mayapada International } \\
\text { Tbk }\end{array}$ \\
\hline 11 & $\mathrm{BCIC}$ & Bank Mutiara Tbk & 26 & MCOR & $\begin{array}{l}\text { Bank Windu Kentjana } \\
\text { International Tbk }\end{array}$ \\
\hline 12 & BDMN & $\begin{array}{l}\text { Bank Danamon Indonesia } \\
\text { Tbk }\end{array}$ & 27 & MEGA & Bank Mega Tbk \\
\hline 13 & BJBR & Bank Jabar Banten Tbk & 28 & NISP & Bank NISP OCBC Tbk \\
\hline 14 & BKSW & Bank Kesawan Tbk & 29 & PNBN & Bank Pan Indonesia Tbk \\
\hline 15 & BMRI & Bank Mandiri (Persero) Tbk & 30 & SDRA & $\begin{array}{l}\text { Bank Himpunan Saudara } 1906 \\
\text { Tbk }\end{array}$ \\
\hline
\end{tabular}

sumber: data diolah

Kelompok objek penelitian bank di Indonesia yang menerapkan internet banking

\begin{tabular}{|l|l|l|}
\hline & BANK & Tahun Awal Operasional \\
\hline 1 & Bank Central Asia & 2001 \\
\hline 2 & Bank Danamon & 2008 \\
\hline 3 & Bank CIMB Niaga & 2000 \\
\hline 4 & Bank Internasional Indonesia & 1998 \\
\hline 5 & Bank Mandiri & 2003 \\
\hline 6 & Bank Permata & 2005 \\
\hline 7 & Bank Negara Indonesia & 2007 \\
\hline 8 & Bank OCBC NISP & 2005 \\
\hline 9 & Bank Mega & 2010 \\
\hline 10 & Bank Bukopin & 2001 \\
\hline 11 & Bank Rakyat Indonesia & 2009 \\
\hline
\end{tabular}

sumber: data diolah 